\title{
Physicochemical and Bacteriological Analysis of Groundwater Quality of Kathmandu Valley
}

\section{Sujan Maharjan ${ }^{1}$, Tista Prasai Joshi ${ }^{1}$ 凶, Rashmi Koju ${ }^{2}$ and Sujan Man Shrestha ${ }^{1}$}

${ }^{1}$ Environment and Climate Study Laboratory, Faculty of Science, Nepal Academy of Science and Technology (NAST), Lalitpur, Nepal

${ }^{2}$ Research Centre for Eco Environmental Sciences, University of Chinese Academy of Sciences *Corresponding author: Tista Prasai Joshi, Nepal Academy of Science and Technology Email: tistaprasai@gmail.com

\begin{abstract}
The limited availability, accessibility and deterioration of the water quality in Kathmandu valley have led to the high demand of ground water. This study aims to evaluate ground water quality of the Kathmandu valley. In this study, the physio-chemical parameters of water samples were performed using standard procedures. Also, total coliforms were enumerated using standard membrane filtration technique to quantify the bacterial contamination. Water samples were collected from July 2017 to July 2018. The results revealed that $56 \%$ and $73 \%$ of well and boring water samples, respectively exceeded standard value of iron recommended by National Drinking Water Quality Standards, 2005. Likewise, ammonia content was higher in $41 \%$ of well water and $35 \%$ of boring water samples than standard. However, few numbers of water samples were contaminated with arsenic $(0.27 \%$ and $2.6 \%$ of well and boring water samples, respectively) and nitrate (3\% and $8 \%$ of well and boring water samples, respectively). Besides, $96 \%$ of well water samples and $88 \%$ of boring water samples were contaminated with total coliform bacteria. Our data indicated that groundwater quality of Kathmandu valley was poor, which was not suitable for direct drinking purposes. Therefore, regular monitoring and treatment of groundwater is recommended before using accordingly.
\end{abstract}

Key words: Ammonia, arsenic, coliform, groundwater,iron, NDWQS, nitrate 


\section{INTRODUCTION}

In this earth, ground water covers approximately $25 \%$ of total fresh water, while surface water covers less than $1 \%$ in resources like rivers, lakes and soil moisture (Alley et al., 1999). Since, ground water is hidden underground, the resource is often overlooked. In Kathmandu valley, the groundwater is profoundly used for drinking and is rapidly increasing in industries, hotels, agriculture and other activities. This has led to all time decline of groundwater level and slowed the recharging of groundwater(Gautam and Prajapati 2014). These ground water has been contaminated by pollutants mixed in surface water and waste water which ultimately gets mixed with the ground water (Pathak et al., 2009). Pollutants such as dissolved organic carbon, ammonia, pathogens and organic compounds as well as heavy metals and trace elements gets drained (leakage) to underground water which affects the quality of ground water aquifer.

During 1971 to 2008, of the 818 cases of drinking water outbreaks reported to CDC's Waterborne Disease and Outbreak Surveillance system (WBDOSS), 30.3\% were associated with untreated groundwater sources (Wallender et al., 2014). While in Nepal, tube wells and shallow wells are mostly used the whole year in water deprived areas. The quality of well water is mostly poor with almost all containing high iron and ammonia. While arsenic contamination is seen in some places in Kathmandu valley(KUKL 2008, Emerman et al. 2010, Gwachha et al. 2020). Groundwater quality assessment is very important in order to find its suitability for intended use. Groundwater quality is mainly dependent upon composition of bed rock, regional climate, soil type and natural and anthropogenic pollution (Andre et al., 2005). Microbial contamination of groundwater is a significant problem particularly, where it is directly used for drinking without any treatment. Coliform bacteria in well water are the major contaminant by organic means through the discharge of sewage and domestic effluents into water sources. Presence of such pathogenic bacteria in groundwater due to environmental pollution is highly undesirable. The objective of this study was to evaluate the physical, chemical and biological parameters of groundwater samples collected from Kathmandu valley and compare the results with National drinking water quality standard (NDWQS 2005). 


\section{MATERIALS AND METHODS}

\section{Sample collection}

The water samples were collected from three cities (Kathmandu, Bhaktapur and Lalitpur) of the Kathmandu valley as shown in Figure 1. Samples were collected in sterilized polyethylene bottles and analyze in the Environmental and climate study laboratory, Nepal Academy of Science and Technology (NAST). Total coliform count of all the water samples was analyzed soon after their arrival into the laboratory following the instructions given in Standard Methods for the Examination of Water and Wastewater (APHA 2005). Water samples were stored at $4{ }^{\circ} \mathrm{C}$ for the further analysis of other physiochemical parameters in order to avoid changes. All chemicals used in this study were of analytical grade. All aqueous solutions were prepared using 18.2 M $\Omega$ water (Millipore, Milli-Q). All glassware was soaked in nitric acid solution $(10 \%)$ for at least 24.0 hours followed by three times rinsing with distilled water and dried at $60{ }^{\circ} \mathrm{C}$ for 4.0 hours before use.

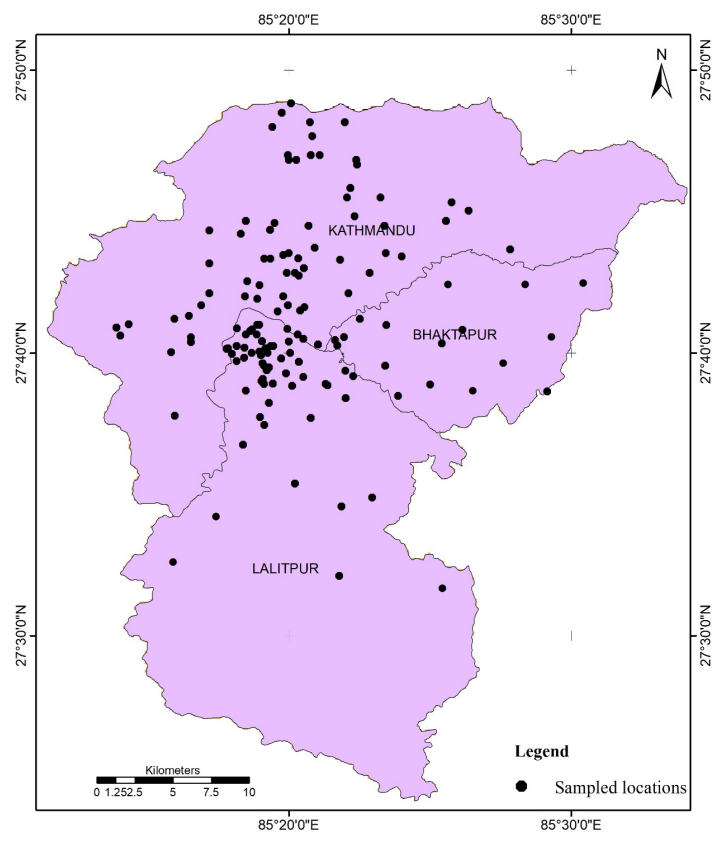

Figure 1: Location of sampling sites in the Kathmandu valley. 


\section{Physicochemical analysis of Ground water}

Temperature and $\mathrm{pH}$ in the sample was measured with the help of a $\mathrm{pH}$ meter (EC-210 Rocker Scientific Co.) by inserting the electrode into the water sample. The Electrical conductivity of the water samples was measured using conductivity meter (HI 8633 HANNA). The electrode was first rinsed with distilled water and then immersed into water sample gently stirred and noted the reading. Turbidity was measured using nephelometer (HI 98713 ISO Turbidimeter HANNA). The sample was put in the clean and scratch free sample tube taking a reference with standard turbidity suspension and noted the reading on the scale.After the measurement of each sample, the probe was rinsed with $18.2 \mathrm{M} \Omega$ water (Millipore, Milli-Q)to avoid cross contamination among different samples.

The total hardness of the water sample was determined by the titration with EDTA. For this $50 \mathrm{~mL}$ of the water sample was taken in a conical flask to which $1 \mathrm{~mL}$ buffer solution was added. Then $200 \mathrm{mg}$ of Erichrome Black T was added as an indicator and the sample was shaken well. The solution turned to wine red in color. Then, the content of the conical flask was titrated against EDTA solution $(0.01 \mathrm{M})$ with continuous stirring which changed the color of the solution from wine red to blue at the end point. The volume of EDTA consumed was noted and total hardness was calculated. The chloride content of the water sample was determined by the Argentometric titration method. For this $50 \mathrm{~mL}$ of water sample was taken in a conical flask to which $2 \mathrm{~mL}$ of $\mathrm{K}_{2} \mathrm{CrO}_{4}$ solution was added. Then the content of the conical flask was titrated against $0.02 \mathrm{MAgNO}_{3}$ until a persistent red tinge appeared. The volume of $\mathrm{AgNO}_{3}$ consumed was noted and the chloride content was calculated. Iron was determined by phenanthroline spectrophotometric method (6715 UV/Vis Spectrophotometer JENWAY). For this $50 \mathrm{ml}$ sample was taken in $100 \mathrm{~mL}$ conical flask to which $2 \mathrm{~mL}$ conc. HCL and $1 \mathrm{~mL}$ of $10 \%$ hydroxylamine hydrochloride solution were added with separate clean pipettes. The contents in the flask were boiled to half of the volume for dissolution of all the iron and then cooled to room temperature and transferred to a $100 \mathrm{~mL}$ volumetric flask. Then, $10 \mathrm{~mL}$ ammonium acetate buffer solution and $2 \mathrm{~mL}$ of $0.1 \%$ phenanthroline solution were added which forms orange red color. It was diluted to $100 \mathrm{~mL}$ distilled water, mixed thoroughly and allowed to stand at least 
10 to 15 minutes for maximum color development. For the determination of Arsenic (QUANTOFIX ${ }^{\circledR}$ Arsenic 10 (Macherey-Nagel Germany)), ammonia (VISOCOLOR ${ }^{\circledR}$ alpha Ammonium(Macherey-Nagel Germany) and nitrate (VISOCOLOR ${ }^{\circledR}$ alpha Nitrate (Macherey-Nagel Germany) were detected by colorimetric method.

\section{Bacteriological Analysis of Ground water}

Total coliform counts were enumerated using the standard membrane filtration (MF) technique as described by APHA (2005). Membrane filters were placed on M-Endo agar plates and incubated overnight at $37^{\circ} \mathrm{C}$. Bacterial colonies were enumerated by colony counter after 24 hours.For this, all sheen-producing colonies were counted. All the instruments and kits used for analysis were according to specified operating procedure of the manufacturing companies. Other methods for water testing were done following the standard methods for the examination of water and wastewater as described by American Public Health Association (APHA 2005).

\section{RESULTS AND DISCUSSION}

Altogether 443 water samples from well and boring water were collected from July 2017 to July of 2018, among which 366 was well water and 77 was boring water. As shown in Figure 2, majority of samples were from Lalitpur district with well $(n=270)$ and boring $(n=24)$, followed by Kathmandu district with well $(n=57)$ and boring $(n=32)$ and Bhaktapur district with well $(n=39)$ and boring water $(n=21)$. The ground water samples consist of well water and boring water obtained from the Kathmandu valley. The well water $(n=366)$ is the most common source used for everyday purpose while boring water $(\mathrm{n}=77)$ is being used in increasing trend in Kathmandu valley. 


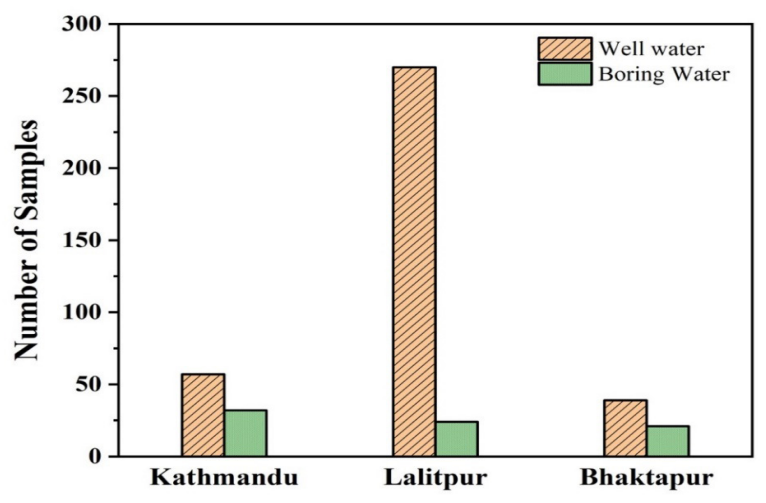

Figure 2: Ground water samples collected from Kathmandu valley

The study revealed that well water exceeds the standard value of NDWQS, 2005 in turbidity $(39 \%)$, conductivity $(2 \%), \mathrm{pH}(15 \%)$, hardness $(1 \%)$, chloride $(0.5 \%)$, iron $(56 \%)$, arsenic $(0.27 \%)$, ammonia (41\%), nitrate $(3 \%)$ and coliform $(96 \%)$. While the boring water samples also crossed above the standard value of NDWQS, 2005 in turbidity (41\%), conductivity (1\%), pH (26\%), iron (73\%), arsenic (2.6\%), ammonia $(35 \%)$, nitrate $(8 \%)$ and coliform $(88 \%)$ as shown in Figure 3.

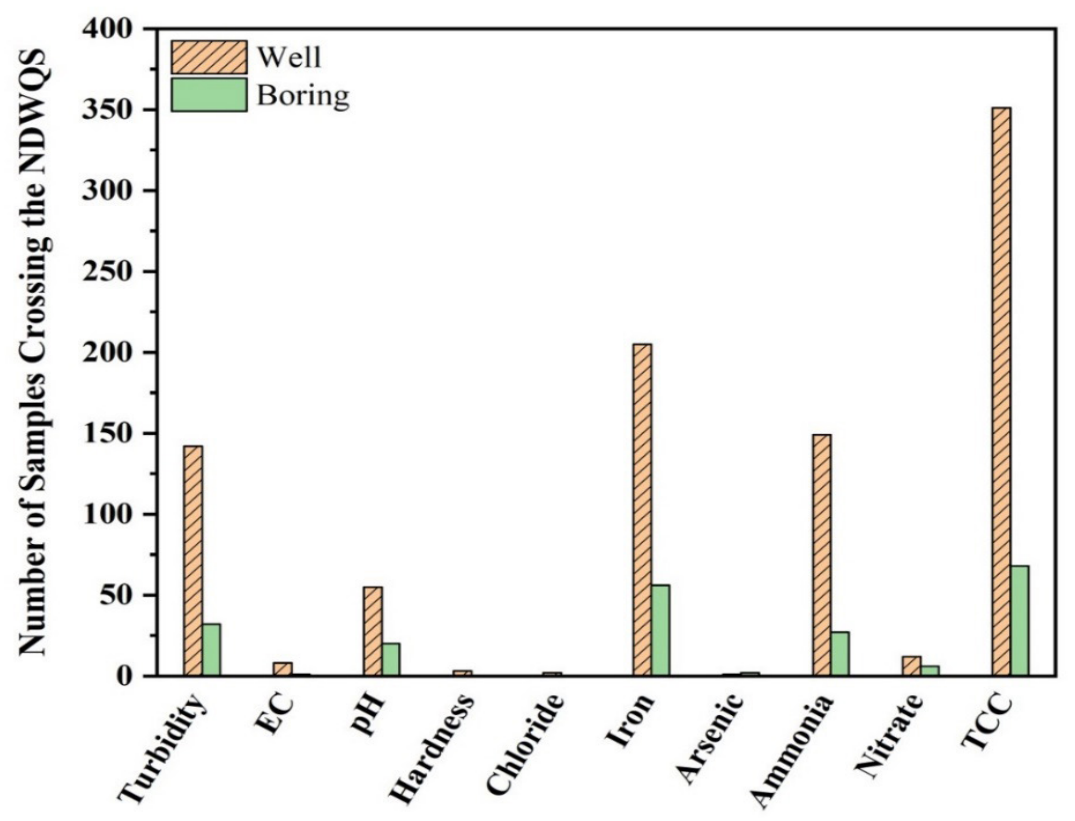


Figure 3: Distribution of well and boring water samples

From the above results, the quality of ground water of Kathmandu valley can be assessed based on National drinking water quality standards of Nepal, 2005 as shown in Table 1.

Table 1: Physicochemical and bacteriological characteristics of Groundwater and National Drinking Water Quality Standards (2005) and WHO Guideline Values (2006)

\begin{tabular}{|c|c|c|c|c|c|c|c|}
\hline Categories & Parameters & Units & Min & Max & Mean & $\begin{array}{l}\text { Standard } \\
\text { values for } \\
\text { Nepal }\end{array}$ & $\begin{array}{l}\text { WHO } \\
\text { guideline }\end{array}$ \\
\hline \multirow[b]{3}{*}{ Physical } & Turbidity & NTU & 0 & 569 & 34.29 & $5(10)$ & 5 \\
\hline & Conductivity & $(\mu \mathrm{S} / \mathrm{cm})$ & 43 & 2880 & 781.97 & 1500 & 500 \\
\hline & $\mathrm{pH}$ & - & 3.4 & 10 & 6.98 & $6.5-8.5$ & $6.5-8.5$ \\
\hline \multirow{6}{*}{ Chemical } & $\begin{array}{c}\text { Total } \\
\text { Hardness }\end{array}$ & $\mathrm{mg} / \mathrm{L}$ & 5 & 666 & 190.40 & 500 & 500 \\
\hline & Chloride & $\mathrm{mg} / \mathrm{L}$ & 4.2 & 291 & 71.15 & 250 & 250 \\
\hline & Iron & $\mathrm{mg} / \mathrm{L}$ & 0 & 16.5 & 1.52 & $0.3(3)$ & 0.3 \\
\hline & Ammonia & $\mathrm{mg} / \mathrm{L}$ & 0 & 0.1 & 2.39 & 1.5 & 1.5 \\
\hline & Nitrate & $\mathrm{mg} / \mathrm{L}$ & 0 & 36 & 9.69 & 50 & 50 \\
\hline & Arsenic & $\mathrm{mg} / \mathrm{L}$ & 0 & 100 & 0.001 & 0.05 & 0.01 \\
\hline Bacteriological & $\begin{array}{c}\text { Total } \\
\text { Coliform } \\
\text { Count }\end{array}$ & $\begin{array}{c}\text { Per } 100 \\
\text { mL }\end{array}$ & 0 & 300 & 278.16 & 0 & 0 \\
\hline
\end{tabular}

The turbidity of well water and boring water was found to be significantly greater than the NDWQS, 2005 value. The highest turbidity values of 569 NTU was recorded in well water sample as given in Table 1. It clearly indicates that there was some kind of contamination in ground water and was not suitable for drinking purpose without treatment. At high levels, turbidity can lead to staining of materials, fittings and clothes exposed during washing, in addition to interfering with the effectiveness of treatment processes (WHO 2017). The conductivity was higher than the standard limit in $2 \%$ samples of well and $1 \%$ sample of boring water. The lowest conductivity values of $43 \mu \mathrm{S} / \mathrm{cm}$ and highest value of $2880 \mu \mathrm{S} / \mathrm{cm}$ were found for boring and well water, respectively. The $\mathrm{pH}$ of well water and boring water was beyond than the standard value by $15 \%$ and $26 \%$ respectively. The $\mathrm{pH}$ value was nearly neutral that ranges from minimum value of 3.4 andmaximum value of 10.0 in well water samples. The result 
was similar to a study conducted by Koju et al in 2014 (Koju et al., 2014), where boring water and well water samples had the $\mathrm{pH}$ values below the permissible value in $9 \%$ and $3 \%$ of samples respectively. While the hardness and chloride values were seen higher in only few cases of well water. The lowest hardness value of $5 \mathrm{mg} / \mathrm{L}$ and highest value of $666 \mathrm{mg} / \mathrm{L}$ were found for boring and well water, respectively. The minimum chloride values of $4.26 \mathrm{mg} / \mathrm{L}$ and highest value of $291 \mathrm{mg} / \mathrm{L}$ were found for boring and well water sample, respectively. In this study, the iron was the predominant contaminant of chemical parameters with $59 \%$ of groundwater has more iron than standard value. While, $56 \%$ of well water and $73 \%$ of boring water had iron beyond the standard limit at the time of analysis. The maximum iron value of $16.5 \mathrm{mg} / \mathrm{L}$ was observed in well water sample. The result was similar to various studies conducted where iron was found to be higher in $22 \%$ of well water samples (Jayana et al., 2009) and $51 \%$ of ground water samples crossed the standard value (Koju et al., 2014).

Arsenic contamination is a life-threatening problem as it may cause dermal changes, cardiovascular, reproductive, mutagenic and carcinogenic. The average arsenic concentrations were 1 and $17 \mu \mathrm{g} / \mathrm{L}$ in shallow and deep groundwater respectively of Kathmandu valley (Shrestha et al., 2012). In the present study, 1 well sample and 2 boring water samples crossed the value of NDWQS, 2005. The highest arsenic content of $0.1 \mathrm{mg} / \mathrm{L}$ was observed in boring and well water sample. In a study carried out to assess arsenic occurrence in groundwater of Kathmandu valley, it was found that $52 \%$ of deep ground water samples exceeded the WHO guideline(Chapagain et al., 2009). This means the deep boring water may be contaminated by arsenic, which is released into the groundwater mainly from natural sources under the reductive process. Ammonia was found to be the second highest chemical contaminant with $40 \%$ of total ground water ( $40 \%$ well and $35 \%$ boring water) samples in this study. The maximum ammonia content of $36 \mathrm{mg} / \mathrm{L}$ was detected in boring water sample. However, ammonia content was reported to be $11 \%$ in ground water (Koju et al., 2014), 7.5\% in well water (Jayana et al., 2009) and 34\% in groundwater (Ghartimagaret al., 2020). The threshold odor concentration of ammonia at alkaline $\mathrm{pH}$ is approximately $1.5 \mathrm{mg} / \mathrm{L}$, and a taste threshold of $35 \mathrm{mg} / \mathrm{L}$ has been proposed for the ammonium cation. Ammonia is not of direct relevance to health at these levels, and no health-based guideline value has been proposed. However, ammonia does react with chlorine to reduce free chlorine 
and to form chloramines (WHO 2017). In this study, nitrate was observed in $4 \%$ of groundwater samples where $3 \%$ of well and $7.7 \%$ of boring water samples exceeded the standard value for nitrate. The highest nitrate value was noted $100 \mathrm{mg} / \mathrm{L}$ in both boring and well water. This is an emerging problem since previous studies did not reported any cases of nitrate in groundwater (Jayana et al., 2009, Koju et al., 2014). An excess of free ammonia entering the distribution system can lead to nitrification and the potential increase of nitrate and nitrite. Nitrate can reach both surface water and groundwater as a consequence of agricultural activity, from wastewater disposal and from oxidation of nitrogenous waste products in human and other animal excreta, including septic tanks. In epidemiological studies, no adverse health effects (Methemoglobinemia or thyroid effects) were reported in infants in areas where drinking-water consistently contained nitrate at concentrations below $50 \mathrm{mg} / \mathrm{L}$ (WHO 2017).In this study, $94.5 \%$ of all ground water samples tested were contaminated by coliform bacteria. Out of which $96 \%$ of well water and $88 \%$ of boring water samples had coliform present. This shows the significant contamination of ground water which may be harmful for direct drinking purposes. The study was similar to previous studies where $100 \%$ of groundwater was contaminated by coliform (Diwakar et al. 2008), $97.37 \%$ of tube well (Bajracharya et al. 2007) and $94.7 \%$ of well water (Prasai et al., 2007). Previous studies evaluating different water sources such as processed water, tap water and treated water revealed that the samples were highly contaminated by total coliform bacteria (Maskey et al. 2020, Maharjan et al. 2018, Bishankha et al. 2012, Shakya et al. 2012). The result was also justified by the previous result where almost all waters of shallow wells were not suitable for drinking because of the presence of E. coli and only $29 \%$ of deep tube wells had drinkable waters (Sakamoto et al., 2012). The detection of coliform bacteria is directly related to public health concerns and it should be monitored for the microbial quality of ground water. For potable use proper treatment of ground water must be done. Therefore, quality of ground water in Kathmandu valley is decreasing condition where serious preventive measures should be taken to conserve this precious resource. Thus, suitable treatment and regular monitoring of the groundwater should be executed as the polluted water quality has direct effects on public health. 


\section{CONCLUSION}

Quality of ground waters of the Kathmandu valley was examined from the viewpoint of physiochemical and microbial parameters. The well water and boring water were mostly incompatible with the National standard of Nepal in term of turbidity, $\mathrm{pH}$, iron, ammonia and total coliform. The results clearly showed the deteriorating conditions of groundwater of Kathmandu valley. Thus, we concluded that groundwater is not directly suitable for drinking purpose and it needs to be treated properly before use.

\section{Acknowledgements}

The authors are grateful to Nepal Academy of Science and Technology for providing the laboratory facilities. We would like to appreciate all the help and efforts provided by the Environment and Climate Study Laboratory members especially Mr. Sujit Dahal and Ms. Smrita Acharya for their help and support.

\section{References}

ALLEY, W.M., REILLY, T.E. and FRANKE, O.L.(1999) Sustainability of ground-water resources, US Department of the Interior, US Geological Survey.

ANDRE, L., FRANCESCHI, M., POUCHAN, P. and ATTEIA, O. (2005) Using geochemical data and modeling to enhance the understanding of groundwater flow in a regional deep aquifer, Aquitain Basin, south-west of France. J Hydrology 305:40-62.

APHA (2005) Standards methods for the examination of water and waste water, American Public Health Association American Water Works Association Pollution Control Federation, Washington DC, USA.

BAJRACHARYA, A., YAMI, K., PRASAI, T., BASNYAT, S., LEKHAK, B. (2007) Assessment of drinking water quality of Kathmandu metropolitan areas. NJST 8: $113-118$.

CHAPAGAIN, S.K., SHRESTHA, S., NAKAMURA, T., PANDEY, V.P., KAZAMA, F. (2009) Arsenic occurrence in groundwater of Kathmandu valley, Nepal. Desalination Water Treat4: 248-254. 
DIWAKAR, J., YAMI, K.D., PRASAI, T. (2008) Assessment of drinking water of Bhaktapur municipality area in pre-monsoon season. Sci World 6(6): 94.

EMERMAN, S.H., PRASAI, T., ANDERSON, R.B. PALMER, M.A. (2010) Arsenic contamination of groundwater in the Kathmandu valley, Nepal, as a consequence of rapid erosion. JNGS 40:49-60.

GAUTAM, D., PRAJAPATI, R.N. (2014)Drawdown and dynamics of groundwater table in Kathmandu Valley, Nepal. OJHM, 8(1).

GHARTIMAGAR, S., KHATRI, P., NEUPANE, S., JOSHI, D., JOSHI, T. (2020) Evaluation of ground water quality of kathmandu valley and antibiotic susceptibility test against Klebsiella pneumoniae. TUJM, 7: 83-90.

GWACHHA, S., ACHARYA, B., DHAKAL, A., SHRESTHA, S., JOSHI, T. (2020) Assessment of arsenic content in deep groundwater of Kathmandu valley, Nepal. NJST 19(1): 69-77.

JAYANA, B.L., PRASAI, T., SINGH, A., YAMI, K.D. (2009) Assessment of drinking water quality of madhyapur-thimi and study of antibiotic sensitivity against bacterial isolates. NJST 10: 167-172.

KOJU, N.K., PRASAI, T., SHRESTHA, S.M., RAUT, P. (2014)Drinking water quality of Kathmandu valley. NJST 15(1): 115-120.

KUKL (2008) Annual Report on Condition and Operation of the Service System, Kathmandu Upatyaka Khanepani Limited Kathmandu, Nepal.

MAHARJAN, S., JOSHI, T.P. SHRESTHA, S.M. (2018) Poor Quality of Treated Water in Kathmandu: Comparison with Nepal Drinking Water Quality Standards. TUJM 5:83-88.

MASKEY, M., ANNAVARAPU, L.S., PRASAI, T. BHATTA, D.R.(2020) Physical, chemical and microbiological analysis of bottled water in Pokhara, Nepal. JCMC 10(2): 25-28. 
NDWQS 2005. National Drinking Water Quality Standard. Ministry of Physical Planning and Works (MoPPW), Government of Nepal, Kathmandu, Nepal.

PATHAK, D.R., HIRATSUKA, A., AWATA, I., CHEN, L. (2009) Groundwater vulnerability assessment in shallow aquifer of Kathmandu Valley using GIS-based DRASTIC model. Environ Geol, 57(7), 1569-1578.

PRASAI, T., LEKHAK, B., JOSHI, D.R., BARAL, M.P. (2007)Microbiological analysis of drinking water of Kathmandu valley. Sci World5: 112-114.

SAKAMOTO, Y., NISHIDA, K., KAZAMA, F., IMAIZUMI, Y., HIRAGA, Y., NAKAMURA, T., CHAPAGAIN, S.K. (2012) Microbial pollution in groundwater and surface water of the Kathmandu valley. 56-63.

SHAKYA, P., JOSHI, T.P., JOSHI, D.R. BHATTA, D.R. (2012) Evaluation of Physicochemical and Microbiological Parameters of Drinking Water Supplied from Distribution Systems of Kathmandu Municipality. NJST 13(2):179-184.

SHRESTHA, S., PRADHANANGA, D. PANDEY, V.P. (2012) Kathmandu valley groundwater outlook, Asian Institute of Technology (AIT), The Small Earth Nepal (SEN), Center of Research for Environment Energy and Water (CREEW), International Research Center for River Basin Environment-University of Yamanashi (ICRE-UY), Kathmandu, Nepal, HYDRO 11: 72-73.

WALLENDER, E. K., AILES, E. C., YODER, J. S., ROBERTS, V. A., \& BRUNKARD, J. M. (2014) Contributing factors to disease outbreaks associated with untreated groundwater. Groundwater, 52(6): 886-897.

WHO (2006) Guidelines for drinking-water quality World Health Organization, Geneva.

WHO (2017) Guidelines for drinking-water quality, World Health Organization, Geneva. 